\title{
Pengaruh Pemanfaatan Hutan Mangrove sebagai Sumber Belajar IPA terhadap Sikap Peduli Lingkungan Siswa Kelas IV SD Kota Bengkulu
}

\author{
Dara Nery Saputri \\ Universitas Bengkulu \\ daranerysa@gmail.com \\ Endang Widi Winarni \\ Universitas Bengkulu, \\ endangwidiw@gmail.com
}

\section{Ansyori Gunawan \\ Universitas Bengkulu, agunawan@unib.ac.id}

\begin{abstract}
The objective of this research is to find out the effect of mangroves usage as the science sources toward the students attitude of caring for the environment (a case study at the fourth grade of elementary school in Bengkulu city). In term of methodology, the researcher used quantitative. Research design in this research used quasi experimental with kind of design using The Matching Only Pretest-Posttest Control Group Design. The subject of the research is the fourth grade students in Bengkulu city. The population is the whole elementary school whose still use KTSP as the curriculum. The test was given to experiment and control class. The questionnaire sheet which consist of declaration's attitude was given at the pretest and posttest. This questionnaire sheet is used as the instrument of the research. The data was analysed using descriptive and inferential analysis which is uji-t. The result of the research showed that the average score of the students posttest from experiment and control class was 98,47 and 91,42. The result of uji-t with thitung 2,59and tabel 2,005 . Therefore $t_{\text {hitung }}>t_{\text {tabel }}$, it can be concluded that the effect or the influence of mangroves usage as the science sources toward the students attitude of caring for the environment (a case study at the fourth grade of elementary school in Bengkulu city) is significant. It's indicate that the election of study sources which contextual and the processing of the good study sources with persuasive message, also attractive for elementary students can be influential toward their attitude.
\end{abstract}

Keyword: mangroves, science, attitude of caring for the environment, study sources 


\begin{abstract}
Abstrak
Tujuan dari penelitian ini adalah untuk mengetahui pengaruh penggunaan mangrove sebagai sumber sains terhadap sikap siswa dalam merawat lingkungan (studi kasus di kelas empat sekolah dasar di kota Bengkulu). Dalam hal metodologi, peneliti menggunakan kuantitatif. Desain penelitian dalam penelitian ini menggunakan quasi eksperimental dengan jenis desain menggunakan The Matching Only Pretest-Posttest Control Group Design. Subjek penelitian adalah siswa kelas IV di kota Bengkulu. Populasi adalah seluruh sekolah dasar yang masih menggunakan KTSP sebagai kurikulum. Tes diberikan kepada kelas eksperimen dan kontrol. Lembar kuesioner yang terdiri dari sikap deklarasi diberikan pada pretest dan posttest. Lembar kuesioner ini digunakan sebagai instrumen penelitian. Data dianalisis menggunakan analisis deskriptif dan inferensial yang merupakan uji-t. Hasil penelitian menunjukkan bahwa skor rata-rata postes siswa dari kelas eksperimen dan kontrol adalah 98,47 dan 91,42. Hasil uji-t dengan thitung 2,59 dan ttabel 2,005. Oleh karena itu thitung $>$ ttabel, dapat disimpulkan bahwa pengaruh atau pengaruh penggunaan mangrove sebagai sumber sains terhadap sikap siswa dalam merawat lingkungan (studi kasus pada kelas empat sekolah dasar di kota Bengkulu) adalah signifikan. Hal ini menunjukkan bahwa pemilihan sumber studi yang kontekstual dan pemrosesan sumber studi yang baik dengan pesan persuasif, juga menarik bagi siswa sekolah dasar dapat berpengaruh terhadap sikap mereka.
\end{abstract}

Kata kunci: hutan bakau, sains, sikap peduli terhadap lingkungan, sumber studi

\title{
Pendahuluan
}

Ilmu Pengetahuan Alam (IPA) sering dianggap hanya sebuah mata pelajaran yang bersifat hafalan. Hal tersebut menyebabkan kurangnya ketertarikan siswa sehingga siswa menjadi malas. Terlihat dari rendahnya kualitas hasil belajar IPA, dibuktikan dengan studi PISA (Program for International Student Assessment) dan TIMSS (Trends in International Mathematics and Science Study) 2015 di Indonesia masih berada di peringkat bawah (Kompas, 2016).

Kondisi memperihatinkan ini harus menjadi cambuk bagi seorang pendidik untuk meningkatkan kualitas pembelajaran IPA.Salah satu usaha dalam meningkatkan kualitas pembelajaran IPA yaitu dengan berinovasi dalam menentukan sumber belajar. Dalam hasil penelitian Nur (2012: 18) menyatakan bahwa buku merupakan sumber belajar IPA yang paling dominan digunakan guru. Pembelajaran tekstual seperti itu sangat disayangkan mengingat IPA merupakan ilmu yang mempelajari fenomena alam. Fenomena tersebut dapat kita jumpai di lingkungan sekitar kita.

Sumber belajar dengan memanfaatkan lingkungan bisa menjadi salah satu pilihan. Diperkuat oleh Istiani dan Retnoningsih (2015: 71), lingkungan yang memiliki daya menjadi sumber belajar dapat memotivasi siswa untuk melakukan kegiatan belajar. Pembelajaran IPA dengan memilih lingkungan sebagai sumber belajar menfasilitasi siswa mendapatkan sumber belajar yang konkret dan lebih kontektual. Hal tersebut selaras dengan Teori Piaget dalam (Winarni, 2012: 7) tentang karakteristik anak usia SD(7-12 tahun)berada dalam tahap operasional konkret. 
Pendekatan "Natural Explorating" menekankan kegiatan belajar yang ada terkait dengan lingkungan alam di sekitar siswa. Sehingga mereka memiliki wawasan yang beragam, belajar tentang berbagai konsep, dan menghubungkan masalah dengan kehidupan nyata masalah (Winarni, 2016a: 2). Jadi, sumber belajar dengan memanfaatkan potensi lokal dapat memilih lingkungan yang terdapat di daerahnya. Secara tofografis, Provinsi Bengkulu terdiri atas dua daratan yaitu daratan tinggi dan daratan rendah (Giyarto, 2012: 1). Salah satu potensi lokal pesisir Bengkulu yang merupakan lingkungan alam adalah hutan mangrove. Hutan mangrove merupakan sekelompok tumbuhan yang terdapat di sepanjang pantai atau muara sungai. Salah satu fungsi hutan mangrove yaitu untuk mencegah abrasi. Dengan bergitu cocok dijadikan sebagai sumber belajar dalam pelajaran IPA yang akan diajarkan yaitu pencegahan kerusakan lingkungan. Diperkuat oleh Magasing (2013: 124) menyatakan terdapat peningkatan hasil belajar dengan menggunakan hutan magrove sebagai sumber belajar.

Hutan mangrove dapat juga dimanfaatkan sebagai sumber belajar dalam berbagai materi lain dalam IPA ataupun pelajaran lain. Dalam pelajaran IPA materi lainnya seperti materi ekosistem, adaptasi mahluk hidup, dan identifikasi bagian tumbuhan. PKn: mengenal dan pemeliharaan lingkungan alam. Bahasa Indonesia: menulis karangan dan laporan hasil pengamatan. IPS: Sumber Daya Alam (SDA), kenampakan alam, potensi lingkungan daerah. SBK: model konkret untuk menggambar dan pembuatan kerajinan dari bahan yang tersedia di hutan mangrove. Pemanfaatan hutan mangrove sebagai sumber belajar sekaligus dapat dijadikan sebagai salah satu usaha pendidikan konservasi. Menurut Savitri (2016: 1112) pembelajaran jelajah alam sekitar (JAS) dapat menumbuhkan softskills mengarahkan ke arah konservasi. Berdasarkan observasi yang telah dilakukan beberapa lahan hutan mangrove di Bengkulu telah ditebang untuk dibangunnya pengerjaan proyek pembangkit listrik Bengkulu, lahan pertambakan, lahan pertanian kelapa sawit, bahkan pemukiman di pesisir. Diperkuat dengan hasil penelitian Edi (2011: 2) permasalahan pokok yang dihadapi oleh ekosistem bakau atau mangrove di Provinsi Bengkulu saat ini adalah kenyataan yang ada telah $50 \%$ hutan mangrove di Bengkulu telah mengalami.Padahal hutan mangrove berperan penting dalam pencegahan abrasi yang sedang dialami.

Salah satu solusi cara pelestarian hutan mangrove yaitu dengan penanaman sikap peduli lingkungan terhadap hutan mangrove melalui pembelajaran yang terintegrasi dengan pembelajaran IPA tentang materi pencegahan kerusakan lingkungan. Peraturan Menteri Pendidikan dan Kebudayaan Nomor 22 Tahun 2016 hasil belajar sikap diperoleh melalui aktivitas "menerima, menjalankan, menghargai, menghayati, dan mengamalkan". Penggunaan lingkungan sebagai sumber belajar dapat menunjang kegiatan pembelajaran secara optimal.

Seorang guru tidak hanya bertugas untuk mengembangkan siswa pada aspek kognitif saja. Guru harus mampu mengembangkan aspek afektifnya juga seperti menanamkan perilaku baik yang akan menjadi karakter siswa. Sikap peduli terhadap lingkungan seharusnya ditanamkan dan dikembangkan sejak dini kepada siswa agar tingkat kepedulian siswa terhadap lingkungan bisa lebih baik. Peneliti memilih pembelajaran IPA sebagai cara untuk mengembangkan sikap peduli lingkungan kepada siswa. Sikap peduli lingkungan mengandung arti sebagai upayaupaya untuk melestarikan, mencegah dan memperbaiki lingkungan alam. Sikap manusia dapat diubah atau dididik melalui suatu pendidikan.

Berdasarkan latar belakang yang telah dikemukakan di atas, maka rumusan masalah dalam penelitian ini adalah: "Apakah terdapat pengaruh pemanfaatan hutan mangrove sebagai sumber belajar IPA terhadap sikap peduli lingkungan siswa kelas IV Sekolah Dasar Kota Bengkulu?" 


\section{Metode}

Metode yang digunakan dalam penelitian ini adalah metode eksperimen. Desain yang digunakan dalam penelitian ini adalah Eksperimental Design dengan jenis desain The Matcing Only Pretest-Posttest Design. Pada desain ini, hanya terdapat kelompok eksperimen dan kelompok kontrol, diberikan tes (test) sebanyak dua kali, yakni pretest dan posttest pada kedua kelompoknya.

Populasi merupakan keseluruhan subyek yang diteliti. Populasi dalam penelitian ini adalah seluruh siswa kelas IV Sekolah Dasar di Kota Bengkulu yang masih menggunakan KTSP. Pengambilan sampel dengan cluster random sampling didapatkan kelas IV SD Negeri 44 Kota Bengkulu yang berjumlah 29 orang siswa sebagai kelas eksperimen dan kelas IVB SD Negeri 60 sebanyak 26 orang sebagai kelas kontrol. Setelah dilakukan uji homogenitas dan dinyatakan kedua kelompok homogen kemudian ditentukan sampel penelitian.

Dalam penelitian ini, instrumen yang digunakan berupa tes dalam bentuk lembar skala sikap yang dibagikan pada pretest dan posttest yaitu berupa lembar tes sebelum dan sesudah mengikuti pembelajaran IPA dengan menggunakan sumber belajar hutan mangrove. Instrumen penelitian ini awalnya hanya berupa kisi-kisi pernyataan yang terlebih dahulu diuji ahli meliputi uji validasi isi dan uji validasi konstruk. Kisi-kisi terdiri dari indikator tanggung jawab, bijaksana, dan menjaga dan menghargai lingkungan. Selanjutnya dilakukan uji coba lapangan di sekolah lain yang setara dan pada kelas yang sama. Peneliti membuat 30 butir pernyataan uji instrumen berupa pernyataan sikap. Berdasarkan hasil dari uji coba instrumen, maka diperoleh yang data validita dan reliabel yaitu sebanyak 23 butir pernyataan.

Teknik pengumpulan data yang digunakan pada penelitian ini adalah tes dalam bentuk pretestposttest. Pretest dan Posttest dalam penelitian ini dilakukan dengan butir pernyataan yang sama. Teknik analisis data dalam penelitian ini adalah analisis kuantitatif dengan menggunakan statistik. Dalam penelitian ini analisis data yang digunakan meliputi uji prasyarat, statistik analisis, dan analisis inverensial. Uji prasyarat meliputi Uji normalitas dengan menggunakan rumus chikuadrat dan uji homogenitas.

\section{Hasil}

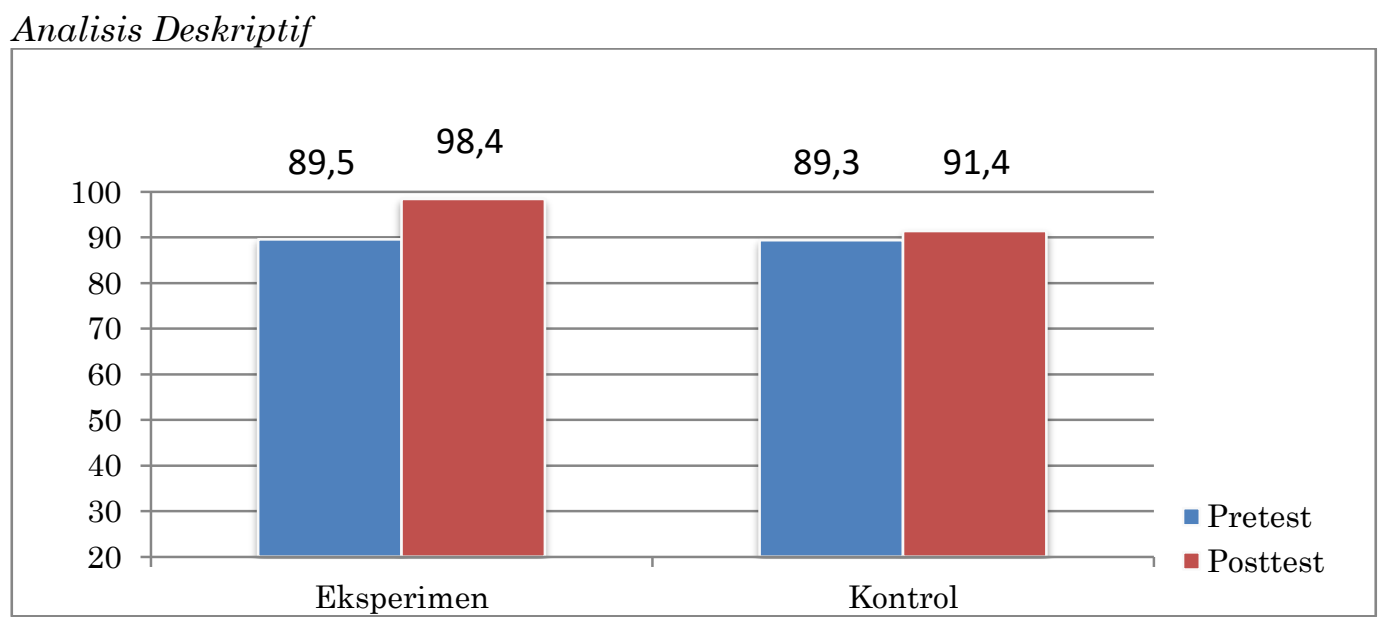

Gambar 4.1. Data Pre test dan Post test Kelompok Eksperimen dan Kelompok Kontrol

Data hasil tes skala sikap ini adalah data yang diperoleh dari lembar pretest siswa. Pemberian lembar pretest ini dilakukan pada kelas kontrol dan eksperimen.Setelah 
dilakukan perhitungan skala sikap. Rata-rata pretest kontrol dan eksperimen diperoleh 89,57 dan 89,35. Hal tersebut menunjukkan bahwa kedua sampel memiliki kemampuan awal yang sama.

Pada kelas eksperimen tes diberikan setelah melakukan pembelajaran dengan sumber belajar hutan mangrove. Sedangkan kelas kontrol dengan menggunakan foto-foto lingkungan hutan mangrove. Hasil Posttest kelompok eksperimen dan kelompok kontrol adalah sebsar 98,47 dan 91,42.

Uji Prasyarat dan Analisis Inferensial

Tabel 1. Hasil Uji-t Pre test dan Post test Pada Kedua Kelompok

\begin{tabular}{|c|c|c|c|c|}
\hline \multirow[t]{2}{*}{ Data } & \multicolumn{2}{|c|}{ Pre test } & \multicolumn{2}{|c|}{ Post test } \\
\hline & $\overline{(E)}$ & (K) & $\mathbf{E}$ & $\bar{K}$ \\
\hline $\mathbf{N}$ & 29 & 26 & 29 & 26 \\
\hline Nilai Min. & 73 & 70 & 79 & 76 \\
\hline Nilai Max & 107 & 105 & 114 & 111 \\
\hline Mean & 89,57 & 89,35 & 98,47 & 91,42 \\
\hline Selisih Rata-rata & \multicolumn{2}{|c|}{0,22} & \multicolumn{2}{|c|}{7,05} \\
\hline Median & 90 & 90 & 100 & 89,5 \\
\hline Modus & 90 & 98 & 102 & 82 \\
\hline$x^{2}$ Standar Deviasi & 9,52 & 8,98 & 10,4 & 10,14 \\
\hline hitung & 5,81 & 5,14 & 8,23 & 4,91 \\
\hline$x^{2}$ & 11,07 & 11,07 & 11,07 & 11,07 \\
\hline$\frac{\mid \text { table }}{\mathbf{F}_{\text {hitung }}}$ & \multicolumn{2}{|c|}{1,12} & \multicolumn{2}{|c|}{1,05} \\
\hline$F_{\text {tabel }}$ & \multicolumn{2}{|c|}{1,93} & \multicolumn{2}{|c|}{1,93} \\
\hline$t_{\text {hitung }}$ & \multicolumn{2}{|c|}{0,09} & \multicolumn{2}{|c|}{2,59} \\
\hline$t_{\text {tabel }}$ & \multicolumn{2}{|c|}{2,005} & \multicolumn{2}{|c|}{2,005} \\
\hline Kesimpulan & Normal & Normal & Normal & Normal \\
\hline Kesimpulan & \multicolumn{2}{|c|}{ Homogen } & \multicolumn{2}{|c|}{ Homogen } \\
\hline Kesimpulan & \multicolumn{2}{|c|}{$\mathrm{H}_{0}$ diterima, $\mathrm{Ha}$ ditolak } & \multicolumn{2}{|c|}{ Ha diterima, $\mathrm{H}_{0}$ ditolak } \\
\hline
\end{tabular}

Berdasarkan data yang diperoleh, menunjukkan bahwa dalam posttest nilai thitung sebesar 2,59 lebih besar daripada nilai tabel pada taraf signifikan $5 \%$ yaitu sebesar 2,005 . Karena nilai thitung $(2,59)>$ tabel $(2,074)$ berarti $\mathrm{H}_{0}$ ditolak dan $\mathrm{H}_{\mathrm{a}}$ diterima, artinya terdapat perbedaan sikap peduli lingkungan siswa pada kelas eksperimen dan kelas kontrol.

\section{Pembahasan}

Sumber belajar adalah suatu bahan yang dapat digunakan dalam proses pembelajaran sebagai pembawa pesan agar dapat mempermudah proses pembelajaran. Sumber belajar dapat mempengaruhi hasil belajar. Diperkuat oleh Magasing (2013: 124) menyatakan terdapat peningkatan hasil belajar dengan menggunakan hutan magrove sebagai sumber belajar. Sesuai dengan hasil 
penelitian ini, pada pemberian pre test antara kelompok eksperimen dan kelompok kontrol menunjukkan bahwa data berdistribusi normal dan homogen. Hasil uji perbedaan pre test antara kelompok eksperimen dan kelompok kontrol menunjukkan thitung lebih kecil dari tabel sehingga $\mathrm{H}_{0}$ diterima dan $\mathrm{Ha}$ ditolak. Artinya tidak terdapat perbedaan yang signifikan pada kedua kelompok ini sehingga dapat ditarik kesimpulan bahwa kedua kelompok memiliki kemampuan awal yang sama.

Dalam penelitian ini terdapat tiga indikator yaitu tanggung jawab, bijaksana, dan menghargai dan menjaga lingkungan. Setelah melakukan analisis dengan mencari persentase pencapaian skor harapan per indikator terdapat peningkatan terlihat pada semua indikator pada kelas eksperimen. Pada kelas kontrol peningkatan hanya pada dua indikator yaitu indikator bijaksana dan menghargai dan menjaga, sedangkan pada indikator tanggung jawab tidak mengalami peningkatan ataupun penurunan. Serta untuk peningkatan secara keseluruhan kelas eksperimen lebih besar dari kelas kontrol.

Pada kelas kontrol pembelajaran hanya menggunakan sumber belajar berupa gambar lingkungan mangrove. Siswa mengamati gambar dalam proses pembelajaran untuk mendapatkan pengetahuan dengan pengetahuan ini siswa dapat melakukan tindakan dengan bijaksana dan perasaan menjaga dan menghargai lingkungan. Siswa tidak berinteraksi langsung dengan hutan mangrove. Dengan begitu siswa tidak memberikan respon yang berarti terhadap hutan mangove menimbulkan tidak adanya peningkatan tanggung jawab terhadap hutan mangrove. Sikap peduli lingkungan terhadap hutan mangrove secara keseluruhan tetap mengalami peningkatan namun lebih rendah dari kelas eksperimen.

Pada kelas eksperimen sumber belajar yang digunakan adalah hutan mangrove. Dimana siswa dibawa langsung ke hutan mangrove untuk melakukan kujungan edukasi. Sebelum melakukan kunjungan siswa mendapatkan arahan. Arahan tersebut memasukan arahan agar siswa tidak melakukan kerusakan di dalam hutan mangrove. Hal tersebut telah mempersuasif siswa agar tetap menjaga dan menghargai lingkungan. Dalam hutan mangrove siswa melakukan percobaan, percobaan bertujuan agar siswa menemukan sendiri pengertian dari abrasi sehingga siswa mengkonstruksi sendiri pengetahuannya. Pengetahuan yang diperoleh siswa menjadi bermakna. Pengetahuan yang bermakna akan mempengaruhi sikap siswa sehinggi siswa bisa menjadi bijaksana dalam bertindak. Pengetahuan yang bukan hanya sekedar konsep yang dihafal namun ditemukan dalam percobaan. Selanjutnya siswa berjelajah lingkungan hutan mangrove dengan mengamati untuk menemukan jawaban dari perbedaan ombak yang menerpa langsung ke pesisir dengan ombak yang menerpa hutan mangrove.

Dengan jelajah ini siswa melihat langsung keadaan hutan mangrove sehingga menimbulkan rasa tanggung jawab dari siswa. Kunjungan edukasi pun diselingi dengan permainan dan acara makan bersama. Pada akhir kegiatan siswa diajak untuk melakukan kebersihan di hutan mangrove. Dalam kegiatan ini siswa dilatih secara langsung untuk bertindak sebagai wujud dari sikap peduli lingkungan. Hingga pada akhirnya siswa pada kelas eksperimen memiliki pengalaman belajar yang lebih dan terjadinya interaksi langsung dengan lingkungan sehingga mempengaruhi sikap peduli lingkungan. Sejalan dengan hasil penelitian Winarni (2016b: 4) yang mengemukakan bahwa lingkungan menyediakan rangsangan terhadap individu dan sebaliknya dengan individu. Individu memberikan respon terhadap lingkungan. Dalam proses interaksi itu dapat terjadi perubahan pada diri individu, berupa perubahan tingkah laku.

Sikap peduli lingungan pun dapat dilihat dari berbagai aspek yang telah menjadi aspek kognitif, afektif, dan konatif. Aspek tersebut menyebar di dalam instrumen 
yang telah dibuat peneliti serta telah dianalisis per aspek. Terdapat peningkatan pesentase skor harapan per aspek baik di kelas eksperimen maupun kelas kontrol. Namun pada kelas eksperimen peningkatan semua aspek lebih besar dari kelas kontrol.

Aspek kognitif yaitu perilaku di mana indivudu mencapai tingkat "tahu" pada objek. Aspek ini mencerminkan representasi atas apa yang dipercayai oleh individu pemilik sikap. Dalam penelitian ini sikap dari persentase skor harapan aspek kognitif pada kelas eksperimen lebih besar dari kelas kontrol. Hal tersebut disebabkan penggunaan sumber belajar yang berbeda. Pada kelas kontrol pembelajaran menggunakan sumber belajar foto-foto lingkungan, siswa dituntut untuk mengamati gambar. Sehingga pembelajaran tidak bersifat konkret dan tidak ada interaksi langsung lingkungan dengan siswa.

Pada kelas eksperimen sumber belajar yang digunakan adalah hutan mangrove, di mana dalam hutan mangrove siswa berinteraksi langsung lingkungan dan melakukan percobaan dengan pasir, rumput, ranting untuk menemukan pengertian abrasi. Serta mengamati langsung hutan mangrove untuk mendapatkan penjelasan bahwa hutan mangrove dapat menahan abrasi. Siswa membangun sendiri pengetahuannya dari apa yang mereka lakukan sehingga pengetahuan tersebut mempengaruhi lebih aspek sikap kognitif lebih besar dari kelas kontrol. Selajan dengan hasil penelitian Dalifa dan Karjiyati (2016: 100) yang menyatakan pengetahuan peduli lingkungan siswa yang belajar dengan metode penemuan lebih baik dari siswa yang belajar dengan metode interaktif.

Aspek afektif yaitu perilaku dimana individu mempunyai kecenderungan untuk suka atau tidak suka pada objek. Pada aspek ini telah muncul perasaan mencintai (sudah melibatkan emosi). Aspek yang banyak dipengaruhi kepercayaan yang diyakini. Dalam peneliti ini persentase skor harapan aspek sikap pada kelas eksperimen lebih besar dari kelas kontrol. Hal tersebut dipengaruhi salah satunya oleh aspek kognitif yang peningkatan pesentasenya lebih besar juga. Suatu yang diyakini sehingga menjadi pengetahuan siswa menyebabkan aspek afektifnya juga tinggi. Selain itu dengan cara membawa siswa langsung ke lingkungan membuat siswa berinteraksi langsung dengan lingkungan. Maka terjadilah interaksi antara siswa dan lingkungan. Pada interaksi tersebut siswa memberikan respon pada lingkungan. Sehingga membuahkan hasil positif lebih pada aspek afektif dibandingkan kelas kontrol yang hanya mengamati gambar. Sejalan dengan Ardianti (2017: 6) yang menerangkan bahwa model EJAS dengan pendekatan science edutainment dapat meningkatkan perilaku peduli lingkungan.

Aspek konatif yaitu perilaku yang sampai tahap hingga individu melakukan sesuatu pada objek. Aspek ini merupakan wujud dari kognitif dan afektif yang dipengaruhi oleh kepercayaan yang diyakini dan perasaan yang sehingga muncullah kecenderungan berperilaku sesuai sikap. Sama halnya dengan aspek kognitif maupun aspek afektif yang mengalami peningkatan pesentase skor harapan lebih besar pada kelas eksperimen dari pada kelas kontrol. Hal tersebut memberikan pengaruh pada peningkatan persentase skor harapan aspek konatif. Selain itu, dalam pembelajaran kelas eksperimen siswa pun melakukan kebersihan dalam hutan mangrove. Suatu tindakan langsung sebagai wujud dari salah satu sikap peduli lingkungan hutan mangrove. Sehingga mempengaruhi sikap dalam aspek konatifnya. Hal tersebut sejalan dengan penelitian Dalifa dan Winarni (2015: 562) yang menyatakan terdapat peningkatan kesadaran lingkungan dengan dalam pembelajaran IPA dengan menggunakan pendekatan lingkungan.

Dalam aspek sikap kognitif dipengaruhi oleh pengatahuan keyakinan siswa, pengetahuan tersebut lebih bermakna ketika siswa membangun sendiri 
pengetahuannya dengan difasilitasi sumber belajar yang berupa lingkungan hutan mangrove. Keyakinan tersebut tertanam dalam pikiran siswa sehingga mempengaruhi perasaan siswa yang kemudian muncul aspek dari afektif yang merupakan ungkapan emosional dari siswa. Ketika siswa telah memiliki pengetahuan dari aspek kognitif dan ditambahkan perasaan dari aspek afektif akan mempengaruhi konatif yang merupakan kecenderungan untuk berperilaku. Terlihat dalam penelitian ini pada peningkatan persentase skor harapan per aspek ketika aspek kognitif mengalami peningkatan maka menyebabkan aspek afektif dan juga aspek kognitifnya mengalami peningkatan.

Dari uraian di atas menyatakkan bahwa sikap seseorang itu dapat diubah oleh sebuah sumber belajar. Sumber belajar berbasis potensi lokal yang merupakan lingkungan alam yaitu hutan mangrove. Hal ini didukung oleh pendapat Azwar yang mengungkapkan bahwa pengubahan sikap pada manusia dapat dilakukan dengan menggunakan suatu strategi persuasif. Dalam persuasi pada umumnya meliputi beberapa unsur yaitu sumber (source) sebagai komunikator yang membawa pesan (message-communication) kepada mereka yang sikapnya hendak diubah (audience). Oleh karena itu, strategi persuasif pada pembelajaran di kelas eksperimen dengan memanfaatan hutan mangrove untuk menjadi sumber belajar dirancang dalam sebuah skenario agar membawa pesan yang dilihat siswa dalam suatu kunjungan edukasi, sehingga pesan tersebut memiliki kekuatan untuk mengajak siswa agar memiliki sikap peduli.

\section{Simpulan}

Berdasarkan hasil penelitian \& pembahasan diperoleh hasil uji perbedaan postest antara kelompok eksperimen dan kelompok kontrol dengan nilai thitung sebesar 2,59 dan tabel sebesar 2,005. Dengan demikian pengujian hipotesis uji-t nilai post test antara kelompok eksperimen dan kelompok kontrol adalah thitung $>t_{\text {tabel }}$ artinya terdapat perbedaan yang signifikan. Sehingga dapat diambil kesimpulan bahwa terdapat pengaruh yang signifikan antara pemanfaatan hutan mangrove sebagai sumber belajar terhadap sikap peduli siswa kelas IV di Sekolah Dasar Kota Bengkulu.

\section{Saran}

Berdasarkan kesimpulan di atas, maka peneliti mengemukakan beberapa saran sebagai berikut.

1. Bagi guru harus sangat memperhatikan keamanan siswa saat melakukan kunjungan salah satunya dengan mengarahkan siswa untuk menggunakan pelampung saat melakukan kegiatan di pinggir pantai. Serta kendaraan harus siap jika sewaktu-waktu cuaca berubah dapat langsung berteduh dan pulang.

2. Bagi siswa diharapkan setelah berkunjung ke hutan mangrove Bengkulu dapat menjaga dan melestarikan hutan mangrove yang ada di sekitar agar hutan tersebut tidak terjadi kerusakan serta untuk mengembangkan sikap peduli siswa.

3. Bagi peneliti selanjutnya untuk melakukan penelitian pengaruh hutan mangrove terhadap keterampilan, pelajaran lain, ataupun dalam pembelajaran tematik.

\section{Referensi}

Ardianti, S.dkk. 2017. Peningkatan Perilaku Peduli Lingkungan dan Tanggung Jawab Siswa Melalui Model Ejas dengan Pendekatan Science Edutainment. Jurnal Ilmiah "PENDIDIKAN DASAR" Vol. IV No. 1 Januari 2017. 
Dalifa \& Karjiyati. V. 2016. Pengaruh Pembelajaran Tematik Menggunakan Pendekatan Saintifik Berbasis Inkuiri dan Interaktif terhadap Pengetahuan Lingkungan dan Pelestarian Biodiversity Bagi Siswa SD 02 Kota Bengkulu. Proceeding of The Internasional Conference on Education, Techology, and Sciences 2016:95-100.

Dalifa \& Winarni, E. W. 2015. Pengembangan model PLH terintegrasi dalam IPA menggunakan pendekatan lingkungan untuk pelestarian biodiversity bagi siswa SD. Prosiding Seminar Nasional Pendidikan 2016: 563.

Edi, K. 2011. Degradasi Mangrove (Hutan Bakau) di provinsi Bengkulu. Jurnal Bengkulu Mandiri.

Giyarto. 2012. Selayang Pandang Bengkulu. Klaten: Intan Pariwara.

Istiani, R.M., \& Retnoningsih, A. 2015. Pemanfaatan Lingkungan Sekolah sebagai Sumber Belajar Menggunakan Metode Post To Post Pada Materi Klasifikasi Makhluk Hidup. Unnes Journal of Biology Education 4 (1) (2015) 70-80.

Kompas. 2016. Imajinasi Siswa Lemah. Tersedia di: http://nasional.kompas.com/read/2016/12/15/23091361/daya.imajinasi.siswa. lemah (diakses tanggal 5 Desember 2017).

Nur, F. M. 2012. Pemanfaatan Sumber Belajar dalam Pembelajaran Sains Kelas V SD pada Pokok Bahasan Makhluk Hidup dan Proses Kehidupan. JESBIO Vol. I No. 1, November 2012.

Winarni, E., W. 2016b. The Influence of a "Natural Exploration" Approach in Developing Environmental Attitudes and Understanding of 3R Principles for Primary School Students. eco-thinking, Volume (1) 2016.

2016b. Pembelajaran Abad 21 Berbasis Karakter dan Lingkungan untuk Mewujudkan Generasi Masa Depan Kreatif, Produktif, dan Afektif. Disajikan pada Seminar Nasional tanggal 8 Oktober 2016 di Universitas Kuningan Jawa Barat.

2012. Inovasi dalam Pembelajaran IPA, Bengkulu: FKIP UNIB.

Magasing, R. 2013) "Pengaruh Pemanfaatan Hutan Mangrove sebagai Sumber Pembelajaran Geografi Terhadap Hasil Belajar”. S2 thesis, Universitas Pendidikan Indonesia.

Savitri, E.N., \& Sudarmin. 2016. Penerapan Pendekatan JAS (Jelajah Sekitar) Pada Mata Kuliah Konservasi dan Kearifan Lokal Untuk Menanamkan Softskills

Konservasi Pada Mahasiswa IPA Unnes. Unnes Science Education Journal. 5(1) 1102-1107. 